\title{
Is the metalloendopeptidase EC 3.4.24.15 (EP24.15), the enzyme that cleaves luteinizing hormone-releasing hormone (LHRH), an activating enzyme?
}

\author{
Kirsty Cleverly ${ }^{1,2}$ and $\mathrm{T}$ John $\mathrm{Wu}^{2}$ \\ ${ }^{1}$ Centre for Medical Education, University of Bristol, 39-41 St Michael's Hill, Bristol BS2 8DZ, UK and ${ }^{2}$ Department of \\ Obstetrics and Gynecology, Uniformed Services University of the Health Sciences, 4301 Jones Bridge Road, Bethesda, \\ Maryland 20814, USA \\ Correspondence should be addressed to TJWu; Email: twu@usuhs.mil
}

K Cleverly is now at Newham University Hospital, Glen Road, London E13 8BL, UK

\begin{abstract}
LHRH (GNRH) was first isolated in the mammalian hypothalamus and shown to be the primary regulator of the reproductive neuroendocrine axis comprising of the hypothalamus, pituitary and gonads. LHRH acts centrally through its initiation of pituitary gonadotrophin release. Since its discovery, this form of LHRH (LHRH-I) has been shown to be one of over 20 structural variants with a variety of roles in both the brain and peripheral tissues. LHRH-I is processed by a zinc metalloendopeptidase EC 3.4.24.15 (EP24.15) that cleaves the hormone at the fifth and sixth bond of the decapeptide $\left(\mathrm{Tyr}^{5}-\mathrm{Gly}^{6}\right)$ to form LHRH-(1-5). We have previously reported that the auto-regulation of LHRH-I (GNRH1) gene expression and secretion can also be mediated by itself and its processed peptide, LHRH-(1-5), centrally and in peripheral tissues. In this review, we present the evidence that EP24.15 is the main enzyme of LHRH metabolism. Following this, we look at the metabolism of other neuropeptides where an active peptide fragments is formed during degradation and use this as a platform to postulate that EP24.15 may also produce an active peptide fragment in the process of breaking down LHRH. We close this review by the role EP24.15 may have in regulation of the complex LHRH system.

Reproduction (2010) 139 319-330
\end{abstract}

\section{Introduction}

LH-releasing hormone (also referred to as GNRH or LHRH) is the central regulator of reproduction via its action upon the hypothalamic-pituitary axis. Neurons that synthesise LHRH secrete their products into the hypothalamo-hypophyseal portal blood to stimulate the release of $\mathrm{LH}$ and $\mathrm{FSH}$ from the anterior pituitary. The release of $\mathrm{LH}$ and $\mathrm{FSH}$, in turn, acts on the gonads to stimulate follicular maturation and eventual ovulation in the female, or sperm maturation in the males (Gore 2002). The anatomical distribution of this hypothalamic hormone is however, much broader than first thought, with expression demonstrated in both neural and nonneural peripheral tissues (Millar 2005). Following processing in specialised hypothalamic neurons, LHRH-I is released in a pulsatile manner and transported to the anterior pituitary via the hypothalamic-hypophyseal portal circulation. Here, LHRH acts via a specific G-protein-coupled receptor (GPCR), the LHRH-receptor (LHRH-R, GNRHR), to control the synthesis and release of the gonadotrophins, LH and FSH (Gore 2002).
In addition to this role, evidence is accumulating for a direct regulatory role in a number of peripheral and nonpituitary neural tissues.

Many laboratories including those of Drs Samuel McCann, Andrew Schally and Roger Guillemin were involved in the characterisation of this neurohormone. The studies from these laboratories led to the elucidation of its structure and functions (Gore 2002, Limonta et al. 2003).

First, discovered and characterised in mammals, the hypophysiotropic form of the peptide (pGlu-His-Trp-SerTyr-Gly-Leu-Arg-Pro-Gly- $\mathrm{NH}_{2}$ ) is part of a much larger family of decapeptides. Over 20 forms of naturally occurring LHRHs have been described in a variety of mammalian and non-mammalian species (Millar 2005). Their nomenclature is originally based upon the species from which they were first described. Furthermore, within each species, there may be one or more LHRH forms where some of these peptide structures are common across species. In this particular review that focuses on mammalian biology and clinical literature, the 
mammalian LHRH is designated LHRH-I as recommended by others (Wray 2002, Schneider et al. 2006).

In the adult, LHRH-I neurons are widely distributed along the rostrocaudal axis in the basal forebrain region around the preoptic area. The brain and pituitary localisation of LHRH has been extensively reviewed elsewhere (Wu et al. 1997, Gore 2002). Studies conducted in a variety of species have identified $\mathrm{LHRH}-\mathrm{I}$ production along with its binding site and cognate receptor, the LHRH-RI, in non-hypothalamic tissue (Leung et al. 2003, Ramakrishnappa et al. 2005, Walters et al. 2008), suggesting a role for this neuroendocrine hormone beyond the pituitary. The wide and varied distribution of LHRH-I underscores the complexity of its function. Much of its biology remains to be elucidated.

Following its release, LHRH is degraded by intracellular peptidases. It has been suggested that the zinc metalloendopeptidase EC 3.4.24.15 (also known as EP24.15 or thimet oligopeptidase) is the main mediator of this process in both the brain and periphery. Other intracellular peptidases, such as the angiotensin-converting enzyme (ACE), in the process of degradation produce peptide fragments with biological activity. When degrading LHRH, EP24.15 produces the pentapeptide fragment $\mathrm{LHRH}-(1-5)$. Work is emerging and suggesting that this peptide fragment has biological activity separate from that of its parent peptide. Biologically, its effects may be different to or even antagonise those of its parent peptide.

In this review, we present the evidence that EP24.15 is the main enzyme of LHRH metabolism. Following this, we look at the metabolism of other neuropeptides where an active peptide fragments is formed during degradation and use this as a platform to postulate that EP24.15 may also produce an active peptide fragment in the process of breaking down LHRH. Evidence is accumulating for clinically important direct peripheral effects of LHRH and LHRH agonists are being widely used for a number of clinical applications. In light of this it is interesting to note that the LHRH agonists in current use are not substrates for EP24.15. We close this review by the role EP24.15 may have in regulation of the complex LHRH system.

\section{LHRH-I is processed by a metalloendopeptidase \\ Processing of neuropeptide}

Neuropeptides form following translation of mRNA in nerve cells to form pro-peptide. Intracellular processing results in an active peptide that is secreted, for example, the pro-hormone of $\mathrm{LHRH}-\mathrm{I}$, is converted into a mature decapeptide in secretory vesicles prior to release. In some cases, several neuropeptides may be cleaved from the same large precursor. For example, proopiomelanocortin can be cleaved to form ACTH, $\alpha \mathrm{MSH}$ and $\beta$-endorphin. The cascade of intracellular processes within nerve cells that results in the formation of active neuropeptides not only regulates the quantity of neuropeptide produced but also its bioactivity. The end result of cleavage of a large precursor molecule is a set of neuropeptides that may have similar, opposite, different or more selective properties. Following secretion into the extracellular area, these neuropeptides may be further processed. The peptide fragments formed following their degradation may provide an additional layer of regulation, demonstrating different effects to their parent peptides.

\section{Zinc metalloendopeptidase EP24.15 has a crucial role in the processing of $\mathrm{LHRH}-\mathrm{I}$}

The $75 \mathrm{kDa}$ EP24.15 is the main enzyme in the metabolism of LHRH-I. This endopeptidase was first identified in the soluble fraction of rat brain homogenates (Orlowski et al. 1983) and is widely distributed in a variety of cell and tissue types (Müller et al. 1997, Tullai et al. 2000, Grundker et al. 2001, Tiong et al. 2004, Ramakrishnappa et al. 2005). Enzymatic activity is dependent upon phosphorylation by protein kinase $\mathrm{A}$ (PKA; Tullai et al. 2000) and as a thermolysin like metalloendopeptidase, the enzyme is zinc dependent (Dong et al. 1993). Substrate specificity is dependent upon peptide size ( $<17$ amino acids), with no clear preference for amino acid sequence (Ray et al. 2004). However, a preference for a hydrophobic amino acid residue in the $\mathrm{P} 1$ and $\mathrm{P} 2$ positions along with a bulky hydrophobic residue in the $\mathrm{P}^{\prime}$ position has been demonstrated (Swanson et al. 2004).

The spatial and temporal location of EP24.15 demonstrates its important role in the processing of $\mathrm{LHRH}-\mathrm{I}$. Confocal microscopy has demonstrated EP24.15 in the external layer of the median eminence and preoptic area, where it can be seen co-localised with LHRH-I axon terminals ( $\mathrm{Wu}$ et al. 1997). For a processing enzyme to play an important physiological role in neuropeptide processing and regulation it must be localised extra-cellularly (Kim et al. 2003). Many enzymes involved in neuropeptide degradation are either anchored to the extracellular membrane or free in the extracellular fluid. EP24.15, however, is predominantly found in the cytoplasm and is secreted into the extracellular space via poorly understood mechanisms. EP24.15 does not contain a membraneanchoring motif yet it has been localised to the extracellular surface of the plasma membrane (Crack et al. 1999) as well as the exofacial leaflet of the lipid raft microenvironment (Jeske et al. 2004). Peripherally, EP24.15 is found in tissues under the control of LHRHI regulation, the highest known levels of being found in the testis. Here, the enzyme's activity levels rise in a linear fashion with age and is thought to have a role in spermatogenesis (Pierotti et al. 1991, Pineau et al. 1999). Levels in the rat ovary are similar to those seen in the brain and increase sharply during puberty (before falling 
away in adulthood; Pierotti et al. 1991). In addition, activity levels fluctuate during the proestrous period in the rat; with peak activity coinciding with the ascending phase of the LH surge (Wu et al. 1997). A regulatory role of circulating steroid hormones in the activity levels of this enzyme has therefore been suggested. Physiological data adds further weight to the idea that EP24.15 is the in vivo processing enzyme of LHRH-I. I.c.v. administration of a specific inhibitor of EP24.15 leads to an eightfold increase in the half-life of LHRH-I (Lasdun et al. 1989) and its peripheral administration augments the LHRH-I dependent surge of LH in the rat (Wu et al. 1997).

Activity of EP24.15 is regulated by phosphorylation of serine residue 644 by PKA. Phosphorylation of this conserved site reduces enzyme affinity for binding LHRH-I. However, once LHRH-I is bound the phosphorylated enzyme can rapidly turn over large quantities of substrate. The ability of phosphorylated EP24.15 to handle large quantities of substrate before saturating adds further evidence for the important regulatory role this enzyme has in the pulsatile LHRH-I waveform (Tullai et al. 2000). Therefore, while other enzymes may also play a role in LHRH-I metabolism, it is proposed that EP24.15 is the prime mediator of LHRH-I degradation in both the brain and periphery. Consequently, regulation of this enzymes activity may provide an additional mechanism of control of reproductive tissue.

\section{Processed peptides have biological activity}

EP24.15 is not the only intracellular peptidase thought to have activities beyond degradation. Other metallopeptidases such as the ACE are known to, in the process of cleavage, activate peptides allowing them to profoundly affect physiology. Some examples to support the concept that active neuropeptides are converted by peptidases to fragments that are biologically active are shown in Table 1.

There are four roles for processed peptides exemplified. Firstly, the processed peptide may be degraded to a peptide demonstrating similar yet weaker action to its parent peptide. For example, angiotensin III has weaker hypertensive properties than angiotensin II. Secondly, processed peptides may show separate actions to their parent peptides. The fragment AVP-(4-9), for example, has no effect on diuresis instead being implicated in social learning and memory (de Wied et al. 1993, Nakayama et al. 2000). Thirdly, processing can result in more specific activity. For example, bradykinin-(1-5) inhibits platelet aggregation in a similar manner to its parent peptide, bradykinin. However, unlike its parent it does not produce vasodilatation making it a potential novel therapeutic (Murphey et al. 2006). Finally, processed peptides can provide counterbalance within a system. This is exemplified by the action of ACE2 on angiotensin II, producing angiotensin-(1-7) (Santos et al. 2008). This peptide opposes the action of angiotensin II, formed by ACE from angiotensin I. Depending on the ratio of activity of these two enzymes; the renin angiotensin system may have vasoconstrictor/proliferative effects (mediated by angiotensin II) or vasodilator/ antiproliferative effects (mediated by angiotensin-(1-7)). Again, the therapeutic modulation of this ratio could have great implications in the treatment of cardiovascular disease.

\section{LHRH-I is metabolised by a two-step process}

The mechanism of metabolism of LHRH suggests that EP24.15 converts rather than degrades the peptide. EP24.15 cleaves LHRH at the Tyr ${ }^{5}-G l y^{6}$ bond producing its major degradation product, LHRH-(1-5). Interestingly, kinetic analysis has shown that LHRH is a poor substrate for EP24.15. However, LHRH-(1-9), a peptide fragment produced by the action of prolyl endopeptidase on LHRH, has a much greater Km (Lew et al. 1994). It is therefore suggested that the conversion of LHRH to its major product LHRH-(1-5) occurs via a two-step mechanism. Firstly, LHRH-(1-9) is generated by prolyl endopeptidase. Conversion by EP24.15 to LHRH-(1-5) then occurs. It is suggested that the carboxy terminal glycine that is removed in the first metabolic step significantly hinders the ability of EP24.15 to cleave LHRH-I.

The two-step mechanism of LHRH metabolism highlights the substrate specificity of EP24.15 suggesting it has a role above simple inactivation. In addition, it has been suggested that a free carboxyl terminus may be required for binding to neutral endopeptidases such as EP24.15 (Orlowski et al. 1983), a similar mechanism seen with the degeneration of LHRH-I and bradykinin by endo-oligopeptidase A. This enzyme will cleave the TyrGly bond only after the removal of glycine from the $\mathrm{COOH}$ terminus (De Camargo et al. 1982). Substituting an amide for the carboxy group reduced hydrolysis, as carboxypeptidases do not cleave alpha amidated peptides efficiently. Therefore, it can be postulated that the carboxy terminal amidation seen in the metabolism of LHRH-I may protect this neuropeptide from nonspecific degredation (Lew et al. 1994).

\section{EP24.15 is an activating enzyme}

EP24.15 is known to degrade a number of important bioactive peptides in addition to LHRH-I, for example bradykinin and neurotensin. Classically, EP24.15, as an endopeptidase is thought to degrade neuropeptides terminating their physiological function. It was initially classified as a metabolising enzyme that terminated function through hydrolysis, rendering its substrate unable to bind to the cognate receptor (Orlowski et al. 1989, Dahms \& Mentlein 1992, Montiel et al. 1997). Current thinking is that EP24.15 has a number of 


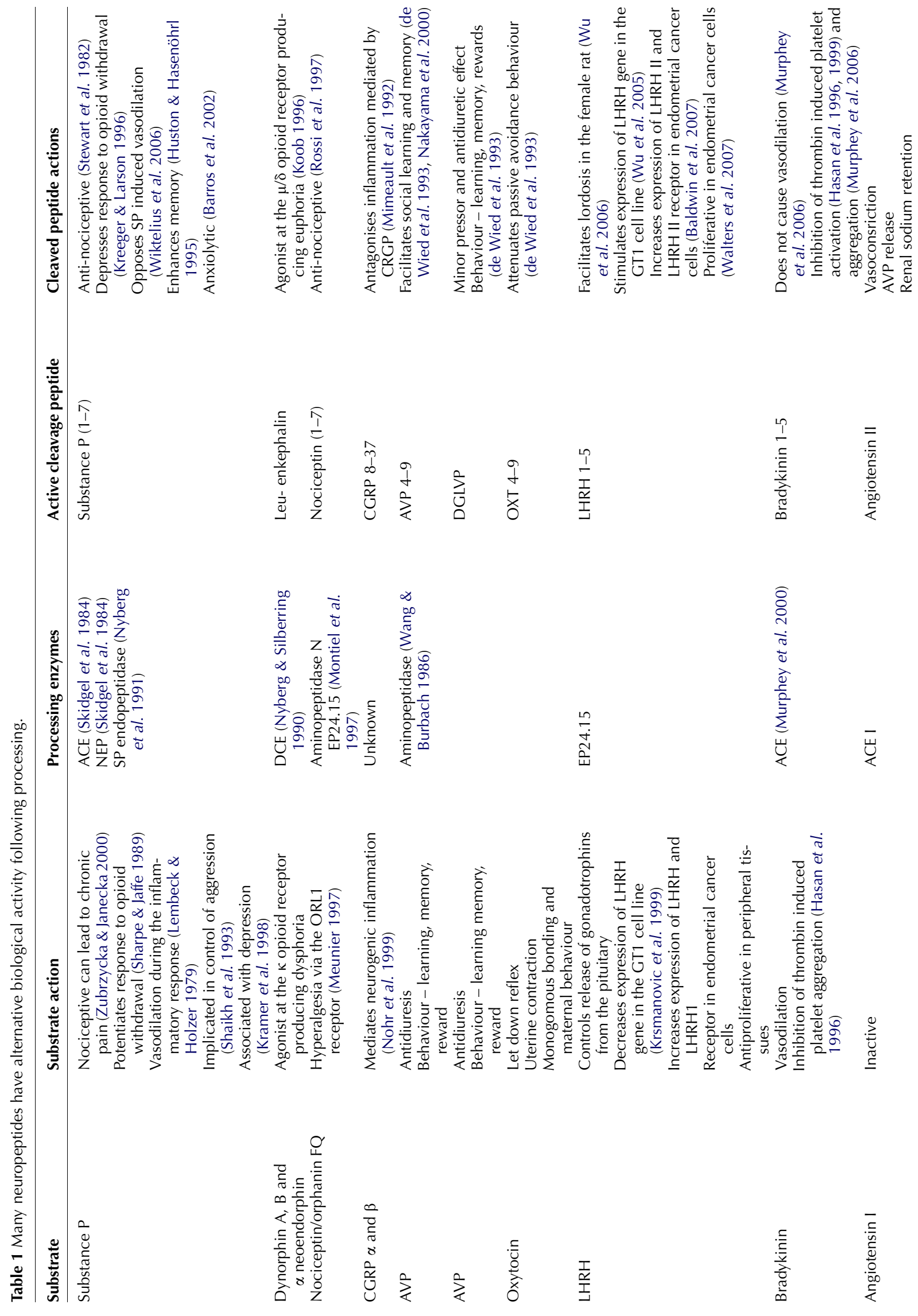



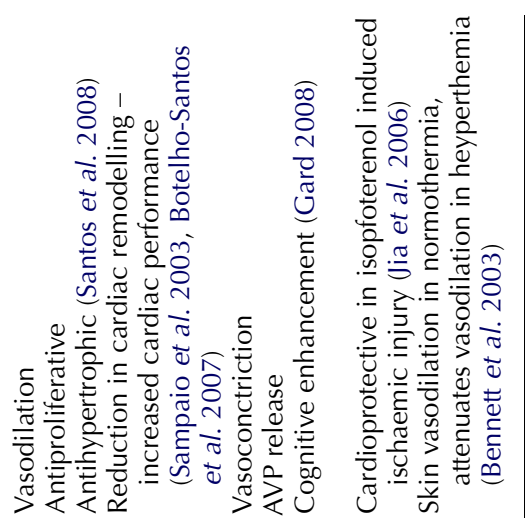

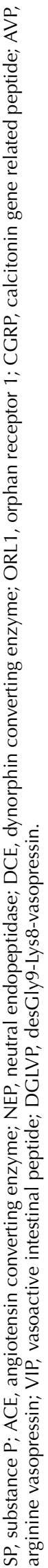

alternative physiological functions (Kim et al. 2003). Firstly, it can transform an inert precursor neuropeptide into an active peptide. This is seen in the activation of neoendorphin (to Leu-enkephalin) by EP24.15 (Acker et al. 1987). Secondly, it acts as a convertase, changing one bioactive peptide into a different peptide that either binds to a different receptor or binds to the same receptor but conveys different downstream messages. For example, EP24.15 can convert the decapeptide LHRH-I to the pentapeptide $\mathrm{LHRH}-(1-5)$. This fragment does not bind to LHRH-RI instead it has antagonistic properties at the $\mathrm{N}$-methyl-D-aspartic acid (NMDA) receptor (Bourguignon et al. 1994). Finally, EP24.15 has a biomodulating action, forming a peptide product that opposes the action of its parent peptide. This is seen with the conversion of angiotensin I to the hypotensive fragment angiotensin-(1-7) by EP24.15 rather than to the hypertensive fragment angiotensin-(1-8) (angiotensin II) by ACE (Chappell et al. 2004).

The many roles of EP24.15 in the metabolism of neuropeptides suggest that this enzyme has a role in cell regulation. Using an inactive EP24.15 'substrate capture' assay in rat brain tissue Cunha et al. (2008) identified nine novel peptides that bound to the enzyme. They subsequently demonstrated that three of these peptides when introduced into CHO-S and HEK293 cells were able to alter GPCR signal transduction. The modulation of GPCR activity was shown to involve the proteins interacting with EP24.15. Adding these peptides intracellularly or overexpression of the enzyme modulated cell functioning suggesting physiological consequences of this signalling effect. This data suggest that EP24.15 and the peptides this enzyme may cleave are regulators of GPCR signal transduction.

\section{Possible role for a metabolite of LHRH-I, LHRH-(1-5)}

Others and our laboratory have hypothesised and shown that LHRH-(1-5), a metabolite of LHRH-I composed of the first five amino acids, may be bioactive (Bourguignon et al. 1994, Wu et al. 2005, 2006, Baldwin et al. 2007, Walters et al. 2007). Previous studies in our laboratory showed that this metabolite stimulates LHRH-I (GNRH1) mRNA expression in the neuronal $\mathrm{GT}_{1-7}$ cell line (Wu et al. 2005). LHRH-I treatment, on the other hand, had a negative regulatory effect on its own expression in the same cells, indicating that these effects are not mediated through the LHRH-RI. Instead it is suggested that LHRH-(1-5) acts via the NMDA receptor (Bourguignon et al. 1994). Therefore, it is proposed that the specific metabolite LHRH-(1-5) is biologically active and acts through a distinct mechanism when compared to its parent molecule (Table 1).

LHRH-(1-5) has also been shown to affect sexual behaviour (Wu et al. 2006). Specifically, i.c.v. administration of LHRH-(1-5) facilitated the lordosis response in ovariectomised female rats. It is interesting to also 
note that LHRH-(1-5) has proliferative effects in the Ishikawa endometrial cell line (Walters et al. 2007) and a number of ovarian surface epithelial cell lines such as those previously shown to be responsive to direct LHRH-I effect (K Walters \& T J Wu, unpublished observations). The ability of LHRH-(1-5) to stimulate proliferation appears to be linked to suppression of caspase-3/7 and ERK-1/2 expression (Walters et al. 2007). It is possible that EP24.15 expression is altered in cancer, resulting in an increase in production of LHRH-(1-5). This in turn may contribute to greater growth and the diminishing role of LHRH-I in regulating the extracellular matrix and activating the apoptosis pathway.

\section{LHRH-I locally regulates healthy reproductive and non-reproductive tissue}

In addition to its central role as a regulator of reproduction there is now much evidence that $\mathrm{LHRH}-\mathrm{I}$ also regulates reproduction at a local level. Given its short half life (2-4 min) in the peripheral circulation (Bennett \& McMartin 1979, Handelsman \& Swerdloff 1986), it is unlikely that LHRH-I from the hypothalamus has a direct effect on peripheral tissue. However, local production of LHRH-I and regulation via an autocrine or paracrine mechanism has been suggested. Metabolism of LHRH by EP24.15 either to LHRH-(1-5) or alternate degradation products presents itself as an additional layer of regulation of this complex system.

\section{Historically, LHRH-I is a regulator of reproduction}

Throughout evolution, the LHRH-I system has been shown to provide a link between the nervous and reproductive systems (Tsai 2006). It has been suggested that the LHRH-I neurons seen in non-chordate invertebrates, who lack a hypothalamic-pituitary-gonadal axis (HPG axis), secreted LHRH-I directly into the blood stream from where it had a direct action on the gonads (Powell et al. 1996, Rastogi et al. 2002). LHRH-I may have developed as an early neuropeptide with a generalised neurotransmitter or neuromodulatory action in simple unicellular and multicellular organisms. As these organisms evolved, LHRH-I could have been recruited by the nerve cells and used to activate reproduction. First by direct action on the gonads and later through the regulation of the pituitary gland (Millar 2005). Early elaboration of LHRH-I function may have involved sensitising the neuroepithelium to pheremones as is seen in bony fish. Therefore, it is suggested that whilst LHRH-I was primarily recruited to regulate reproduction via the HPG axis it may maintain a regulatory role in peripheral reproductive and nonreproductive tissues.

\section{LHRH and its receptor are present in peripheral reproductive tissues}

LHRH-I and its cognate receptor have been co-localised in a number of tissues, mainly of the reproductive system (e.g. breast (Kottler et al. 1997, Limonta et al. 2003, Harrison et al. 2004), gonads (Clayton et al. 1992, Bull et al. 2000, Choi et al. 2006), prostate (Limonta et al. 1999, Tieva et al. 2001), endometrium (Murdoch 1995, Raga et al. 1998), oviduct (Casan et al. 2000) and placenta (Wolfahrt et al. 1998, Chou et al. 2004)). For example, in healthy breast tissue RT-PCR has been used to identify both LHRH-I and LHRH-RI (Kottler et al. 1997) while in the ovary, in situ hybridisation and RT-PCR have been employed to identify LHRH mRNA in the granulose cells of primary, secondary and tertiary follicles and the mRNA of LHRH-RI in human granulose luteal cells (Ramakrishnappa et al. 2005). Interestingly, tumours originating from these tissues (e.g. ovarian (Ohno et al. 1993, Irmer et al. 1995, Arencibia \& Schally 2000, Kang et al. 2000), endometrial (Irmer et al. 1994), prostatic (Limonta et al. 1993, Bahk et al. 1998, Lau et al. 2001) and breast (Harris et al. 1991, Kottler et al. 1997)) also contain a high level of LHRH-RI. As previously described, EP24.15 has a similarly wide distribution in reproductive tissues.

Evidence for the presence of $\mathrm{LHRH}$-I gene transcripts, binding sites and mRNA have been demonstrated in the rat ovary. Although data from human ovaries has been more variable, LHRH-I and LHRH-RI mRNA has been demonstrated using RT-PCR in both the fresh and cultured granulose luteal cells of women undergoing IVF (Peng et al. 1994, Minaretzis et al. 1995). More specifically in situ autoradiography has shown high affinity binding of LHRH-I to the granulose cells of the dominant follicle with low affinity binding sites seen in corpus luteum homogenates (Bramley et al. 1985, Latouche et al. 1989).

\section{LHRH has direct antiproliferative effects in reproductive tissues}

LHRH-I is known to induce apoptosis in healthy rat ovarian granulosa cells via unknown mechanisms (Yano et al. 1997). In ovarian cancer cells LHRH-I induces apoptosis via stimulation of Fas ligand (Imai et al. 1998). In the pituitary, activation of the GPCR LHRH-RI results in activation of MAPK cascades via tyrosine kinase, calcium and protein kinase C-dependent mechanisms. These cascades alter growth factor signalling via ERK and apoptosis via the p38 MAPK kinase. It is unknown whether downstream signalling of the peripheral LHRH$\mathrm{RI}$ resembles that of the pituitary LHRH-R. In human gynaecological tumours, LHRH-I signalling neutralises epidermal growth factor tyrosine kinase activity and down regulates its receptors via the activation of phosphotyrosine phosphatase (Imai et al. 1996). 
This occurs via coupling to the Gai protein, one explanation of this differing effect (Wu et al. 2009). The emerging evidence regarding $\mathrm{LHRH}-(1-5)$ suggests that this active peptide fragment has a proliferative effect on tumour cells. The downstream signalling pathway of this effect is as yet unknown but one could speculate as to a balanced regulatory system with proliferation being influenced by varying levels of LHRH and LHRH-(1-5). The enzyme EP24.15 and regulation of its activity could therefore have a role in cellular proliferation of reproductive tissues.

\section{LHRH agonists are not degraded by EP24.15}

The LHRH analogues (e.g. buserelin, goserelin, leuprolide, nafarelin and triptorelin) are used in the treatment of a number of hormonally responsive tissues. Injections of such analogues result in downregulation of pituitary LHRH-I receptors and desensitisation of gonadotroph cells, inducing a pharmacological castration (Conn \& Crowley 1994). LHRH released from the hypothalamus is not present in the peripheral circulation and it is possible that peripheral production of $\mathrm{LHRH}$ is altered in pathological tissues; however, depot injection of an LHRH analogue has been shown to produce measurable circulating levels of LHRH. These 'super agonists' have increased receptor affinity and a high biological stability due to modification of the $\mathrm{Tyr}^{5}$-Gly ${ }^{6}$ residues. Interestingly, this modification renders these agonists resistant to cleavage by EP24.15. Additionally, incubation of EP24.15 with varying concentrations of LHRH-I analogue before assessing enzyme function revealed that most of the LHRH-I analogues used in clinical practice are inhibitory to this enzyme's activity (Fig. 1). Increasing the size and hydrophobic nature of the residue in position 6 accentuated this inhibition (Cummins et al. 1999). Evidence for an additional role of these analogues, where effect comes from a direct interaction of analogue and $\mathrm{LHRH}$ receptors within diseased tissue is growing. Scrutiny of this evidence adds a further dimension to possible activating role of EP24.15, as while LHRH-1 and LHRH-(1-5) are likely to act via different pathways, the fact that LHRH-(1-5) is not produced by these analogues may go some way to explaining the differing effects of $\mathrm{LHRH}$ and LHRH agonists.

\section{The LHRH system is active in peripheral tissue}

Anatomical data has demonstrated LHRH-I and its receptor in the majority of reproductive tissue cancers. Receptor transcripts have been shown in around $80 \%$ of primary ovarian and endometrial tumours (Imai et al. 1994) with $50 \%$ of breast cancers expressing LHRH-I binding sites (Fekete et al. 1989). The coding for this receptor in breast and ovarian tumours is identical to the pituitary LHRH-RI (Kakar et al. 1994). Production of LHRH-I has been demonstrated in human breast, prostatic, ovarian and endometrial cancer cell lines (Emons \& Schally 1994, Schally 1999, Schally et al. 2001). Additionally, the LHRH-I system has been seen in hormonally unresponsive malignancies (Jungwirth et al. 1998, Moretti et al. 2002, Keller et al. 2005). Whilst the function and downstream effect following activation of

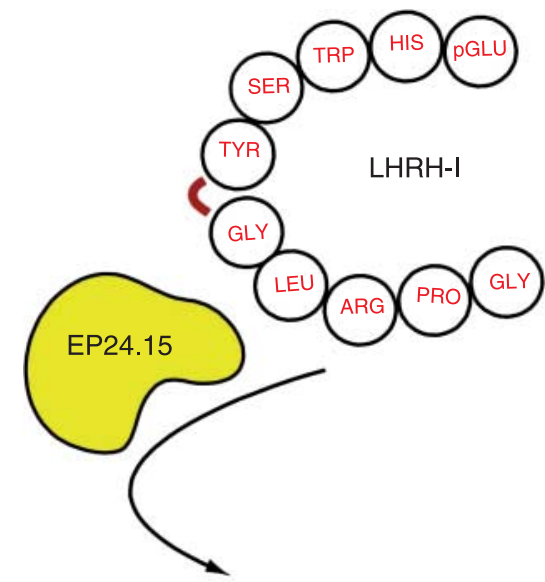

LHRH-(1-5)

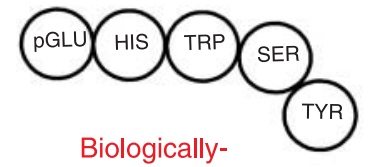

active processed peptide

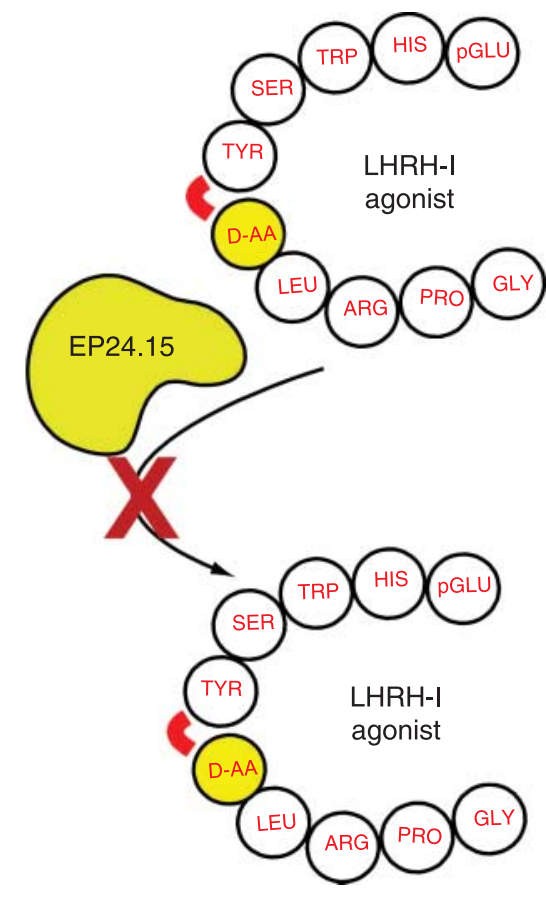

Figure $1 \mathrm{~A}$ diagram showing LHRH-I in the folded conformation with the $\mathrm{Tyr}^{5}$-Gly ${ }^{6}$ bond available for hydroysis by EP24.15. Substitutions with D-amino acids in the sixth position (Gly) (labelled $\mathrm{D}-\mathrm{AA}$ in the figure) increases binding affinity to the LHRH-R but prevents hydrolysis. EP24.15 cleaves LHRH-I to produce LHRH-(1-5), whereas it does not cleave LHRH-I agonists containing substitutions of D-amino acids in the sixth position. 
this receptor remain contentious, one can speculate about a local regulatory system based around LHRH-I. LHRH-RI activation in cultured tumour cells has antiproliferative and pro-apoptotic effects (Hsueh \& Jones 1982, Ikeda et al. 1996, Pineau et al. 1999, Limonta et al. 2003) led to the proposal that the LHRH-R system may act as a local negative regulator of tumour growth.

\section{Prostate tissue}

LHRH-I analogues have been used in the treatment of prostate cancer since the early 1980's (Labrie et al. 1982, Plosker \& Brogden 1994). In the androgendependent phase of the disease their major effect is via suppression of the HPG axis, with an early worsening of symptoms (e.g. pain from bone metastasis) frequently observed prior to agonist induced suppression of pituitary function, an effect that can be reversed with use of anti-androgens (Sogani \& Fair 1987). Evidence for an additional direct effect comes from in vitro experiments where LHRH-I agonists exert an inhibitory effect on the androgen induced proliferation of prostate cancer cells in a dose-dependent manner (Limonta et al. 1992, 1999). When the cell line ALVA31 was xenografted into surgically castrated male mice, treatment with leuprolide inhibited its growth (Loop et al. 1995). These results suggest an alternative mechanism of LHRH-I action independent of the suppressive effect on the HPG axis. Prostate cancer tends to progress to a stage of androgen independence. It has been suggested that in this phase LHRH-I agonists may have a direct anti-tumour effect. In androgen insensitive prostate cancer cells, treatment with LHRH-I results in blockade of the fibroblast growth factor induced proliferation and invasion only in tumour cells with very high expression levels of LHRH-RI (Gnanapragasam et al. 2005). LHRH-I agonist therapy was then shown to improve survival only in patients with a high expression of LHRH-IR, an effect not seen when this subset of patients underwent surgical castration.

\section{Mammary tissue}

LHRH-I agonists are used as adjuvant therapy in oestrogen receptor (ER) or progesterone receptor positive pre-menopausal breast cancer as well as in salvage therapy for advanced disease. Interestingly, the combined effect of ER blockade (with tamoxifen) and LHRH-I agonist treatment was shown to be superior to either individual treatment in early breast cancer (Klijn et al. 2001). Whether this is due to suppression of the tamoxifen induced stimulation of pituitary function or due to a direct effect of the LHRH-I analogue on breast cancer cells remains to be determined. Evidence for the latter explanation comes from in vitro studies on the oestrogen insensitive breast cancer cell line, MDA-MB 231, in which LHRH-I was anti-proliferative. This effect remained when the cells were xenografted into mice (Vincze et al. 1991). The absence of active ERs on this cell line suggests an effect of LHRH-I above suppression of circulating levels of sex steroids.

LHRH-I produced peripherally acts via its cognate receptor on a number of peripheral reproductive tissues. This direct local effect on both healthy and diseased tissue has a number of clinical implications. Further understanding of the regulation of this system is needed before the full scope of their potential clinical use can be described. Specifically, there is the possibility of an additional level of regulation, via the downstream processing of this peripherally produced LHRH by EP24.15.

\section{Summary}

The classical action of LHRH-I analogues is depression of pituitary gonadotrophs with consequent suppression of gonadal function. The evidence presented here suggests that in addition LHRH-I analogues may have direct effects on both healthy and diseased reproductive tissues where it is seen to regulate cellular growth. $\mathrm{LHRH}-\mathrm{I}$ was named after its first known function, control of pituitary release of LH. Subsequently, this neuropeptide has been shown to have a diversity of location and action that extends far beyond its current nomenclature.

It is known that pro-hormone precursors are cleaved to form variety of neuropeptides often with different actions. In this review an additional layer of regulation is proposed; that is that following secretion neuropeptides are further cleaved to form additional active peptide fragments. LHRH-I is processed by the endopeptidase, EP24.15, to form LHRH (1-5), a fragment that has contrasting biological activity to its parent peptide. Levels of EP24.15 may be used to balance the action of the different peptides, both centrally and peripherally. Disruption of this regulation may lead to disordered cellular proliferation with consequent pathology.

The LHRH-I agonists in current clinical use are not substrates for EP24.15. Their use may shift the balance of LHRH-I activity in peripheral tissues towards antiproliferation. This is a potential additional explanation for the peripheral actions of these drugs. In addition further description of the action and receptor of LHRH (1-5) may present a possible therapeutic target for antiproliferatives.

\section{Declaration of interest}

The authors declare that there is no conflict of interest that could be perceived as prejudicing the impartiality of the research reported. 


\section{Funding}

This work was supported by National Science Foundation grants IBN-0315023 and IOB-0544150 ( $\mathrm{T} \mathrm{J} \mathrm{Wu}$ ), and Department of Defence grant CO85AO (T J Wu).

\section{Acknowledgements}

We wish to thank Professor Stafford Lightman and Dr John Farley for critically reading this review. The opinions or assertions contained herein are the private ones of the authors and are not to be considered as official or reflecting the views of the Department of Defence or the Uniformed University of the Health Sciences.

\section{References}

Acker GR, Molineaux C \& Orlowski M 1987 Synaptosomal membrane bound form of endopeptidase-24.15 generates Leu-enkephalin from dynorphin 1-8, alpha- and beta-neoendorphin, and Met-enkephalin from Met-enkephalin-Arg6-Gly7-Leu8. Journal of Neurochemistry 48 284-292.

Arencibia JM \& Schally AV 2000 Luteinizing hormone-releasing hormone as an autocrine growth factor in ES-2 ovarian cancer cell line. International Journal of Oncology 16 1009-1013.

Bahk JY, Hyun JS, Lee H, Kim MO, Cho GJ, Lee BH \& Choi WS 1998 Expression of gonadotropin-releasing hormone $(\mathrm{GnRH})$ and $\mathrm{GnRH}$ receptor mRNA in prostate cancer cells and effect of $\mathrm{GnRH}$ on the proliferation of prostate cancer cells. Urological Research 26 259-264.

Baldwin EL, Wegorzewska IN, Flora M \& Wu TJ 2007 Regulation of type II luteinizing hormone-releasing hormone (LHRH-II) gene expression by the processed peptide of LHRH-I, LHRH-(1-5) in endometrial cells. Experimental Biology and Medicine 232 146-155.

Barros M, De Souza Silva MA, Huston JP \& Tomaz C 2002 Anxiolytic-like effects of substance $P$ fragment $(\mathrm{SP}(1-7))$ in non-human primates (Callithrix penicillata). Peptides 23 967-973.

Bennett HPJ \& McMartin C 1979 Peptide hormones and their analogues: distribution, clearance from the circulation, and inactivation in vivo. Pharmacological Reviews 30247.

Bennett LA, Johnson JM, Stephens DP, Saad AR \& Kellogg DL Jr 2003 Evidence for a role for vasoactive intestinal peptide in active vasodilatation in the cutaneous vasculature of humans. Journal of Physiology 552 223-232.

Botelho-Santos GA, Sampaio WO, Reudelhuber TL, Bader M, Campagnole-Santos MJ \& Souza dos Santos RA 2007 Expression of an angiotensin-(1-7)-producing fusion protein in rats induced marked changes in regional vascular resistance. American Journal of Physiology. Heart and Circulatory Physiology 292 H2485-H2490.

Bourguignon JP, Alvarez Gonzalez ML, Gerard A \& Franchimont P 1994 Gonadotropin releasing hormone inhibitory autofeedback by subproducts antagonist at $\mathrm{N}$-methyl-D-aspartate receptors: a model of autocrine regulation of peptide secretion. Endocrinology 134 1589-1592.

Bramley TA, Menzies GS \& Baird DT 1985 Specific binding of gonadotrophin-releasing hormone and an agonist to human corpus luteum homogenates: characterization, properties, and luteal phase levels. Journal of Clinical Endocrinology and Metabolism 61 834-841.

Bull P, Morales P, Huyser C, Socias T \& Castellon EA 2000 Expression of $\mathrm{GnRH}$ receptor in mouse and rat testicular germ cells. Molecular Human Reproduction 6 582-586.

Casan EM, Raga F, Bonilla-Musoles F \& Polan ML 2000 Human oviductal gonadotropin-releasing hormone: possible implications in fertilization, early embryonic development, and implantation. Journal of Clinical Endocrinology and Metabolism 85 1377-1381.

Chappell MC, Modrall JG, Diz DI \& Ferrario CM 2004 Novel aspects of the renal renin-angiotensin system: angiotensin-(1-7), ACE2 and blood pressure regulation. Contributions to Nephrology 143 77-89.
Choi JH, Gilks CB, Auersperg N \& Leung PC 2006 Immunolocalization of gonadotropin-releasing hormone $(\mathrm{GnRH})-\mathrm{I}, \mathrm{GnRH}-\mathrm{II}$, and type I GnRH receptor during follicular development in the human ovary. Journal of Clinical Endocrinology and Metabolism $914562-4570$.

Chou CS, Beristain AG, MacCalman CD \& Leung PC 2004 Cellular localization of gonadotropin-releasing hormone $(\mathrm{GnRH})$ I and $\mathrm{GnRH}$ II in first-trimester human placenta and decidua. Journal of Clinical Endocrinology and Metabolism 89 1459-1466.

Clayton RN, Eccleston L, Gossard F \& Morel G 1992 Rat granulosa cells express the gonadotropin-releasing hormone gene: evidence from in situ hybridisation. Journal of Molecular Endocrinology 9 189-195.

Conn PM \& Crowley WF Jr 1994 Gonadotropin-releasing hormone and its analogs. Annual Review of Medicine 45 391-405.

Crack PJ, Wu TJ, Cummins PM, Ferro ES, Tullai JW, Glucksman MJ \& Roberts JL 1999 The association of metalloendopeptidase EC 3.4.24.15 at the extracellular surface of the AtT-20 cell plasma membrane. Brain Research 835 113-124.

Cummins PM, Pabon A, Margulies EH \& Glucksman MJ 1999 Zinc coordination and substrate catalysis within the neuropeptide processing enzyme endopeptidase EC 3.4.24.15. Identification of active site histidine and glutamate residues. Journal of Biological Chemistry 274 16003-16009.

Cunha FM, Berti DA, Ferreira ZS, Klitzke CF, Markus RP \& Ferro ES 2008 Intracellular peptides as natural regulators of cell signaling. Journal of Biological Chemistry 283 24448-24459.

Dahms P \& Mentlein R 1992 Purification of the main somatostatin degrading proteases from rat and pig brains, their action on other neuropeptides and their identification as endopeptidases 24.15 and 24.16. European Journal of Biochemistry 208 145-154.

De Camargo AC, Da Fonseca MJ, Caldo H \& De Morais Carvalho K 1982 Influence of the carboxyl terminus of luteinizing hormone-releasing hormone and bradykinin on hydrolysis by brain endo-oligopeptidases. Journal of Biological Chemistry 257 9265-9267.

Dong KW, Yu KL \& Roberts JL 1993 Identification of a major up-stream transcription start site for the human progonadotropin-releasing hormone gene used in reproductive tissues and cell lines. Molecular Endocrinology 7 1654-1666.

Emons G \& Schally AV 1994 The use of luteinizing hormone releasing hormone agonists and antagonists in gynecological cancers. Human Reproduction 9 1364-1379.

Fekete M, Wittliff JL \& Schally AV 1989 Characteristics and distribution of receptors for [D-Trp6]-luteinizing hormone-releasing hormone, somatostatin, epidermal growth factor and sex steroids in 500 biopsy samples of human breast cancer. Journal of Clinical Laboratory Analysis 3 137-147.

Gard PR 2008 Cognitive-enhancing effects of angiotensin IV. BMC Neuroscience 9 S15.

Gnanapragasam VJ, Darby S, Khan MM, Lock WG, Robson CN \& Leung HY 2005 Evidence that prostate gonadotropin-releasing hormone receptors mediate an anti-tumourigenic response to analogue therapy in hormone refractory prostate cancer. Journal of Pathology 206 205-213.

Gore AC 2002 GnRH: The Master Molecule of Reproduction. Norwell, MA: Kluwer Academic Publishers.

Grundker C, Volker P \& Emons G 2001 Antiproliferative signaling of luteinizing hormone-releasing hormone in human endometrial and ovarian cancer cells through $\mathrm{G}$ protein alpha(I)-mediated activation of phosphotyrosine phosphatase. Endocrinology 142 2369-2380.

Handelsman DJ \& Swerdloff RS 1986 Pharmacokinetics of gonadotropinreleasing hormone and its analogs. Endocrine Reviews 7 95-105.

Harris N, Dutlow C, Eidne K, Dong KW, Roberts J \& Millar R 1991 Gonadotropin-releasing hormone gene expression in MDA-MB-231 and ZR-75-1 breast carcinoma cell lines. Cancer Research 51 2577-2581.

Harrison GS, Wierman ME, Nett TM \& Glode LM 2004 Gonadotropinreleasing hormone and its receptor in normal and malignant cells. Endocrine-Related Cancer 11 725-748.

Hasan AA, Amenta S \& Schmaier AH 1996 Bradykinin and its metabolite, Arg-Pro-Pro-Gly-Phe, are selective inhibitors of alpha-thrombin-induced platelet activation. Circulation 94 517-528.

Hasan AA, Rebello SS, Smith E, Srikanth S, Werns S, Driscoll E, Faul J, Brenner D, Normolle D, Lucchesi BR et al. 1999 Thrombostatin inhibits induced canine coronary thrombosis. Thrombosis and Haemostasis $\mathbf{8 2}$ 1182-1187. 
Hsueh AJ \& Jones PB 1982 Regulation of ovarian granulosa luteal cell functions by gonadotropin releasing hormone and its antagonist. Advanced Experimental Medical Biology 147 223-262.

Huston JP \& Hasenöhrl RU 1995 The role of neuropeptides in learning: focus on the neurokinin substance P. Behavioral Brain Research 66 $117-127$.

Ikeda M, Taga M, Sakakibara H, Minaguchi H, Ginsburg E \& Vonderhaar BK 1996 Gene expression of gonadotropin-releasing hormone in early pregnant rat and steroid hormone exposed mouse uteri. Journal of Endocrinological Investigation 19 708-713.

Imai A, Ohno T, lida K, Fuseya T, Furui T \& Tamaya T 1994 Presence of gonadotropin-releasing hormone receptor and its messenger ribonucleic acid in endometrial carcinoma and endometrium. Gynecologic Oncology 55 114-118.

Imai A, Takagi H, Horibe S, Fuseya T \& Tamaya T 1996 Coupling of gonadotropin-releasing hormone receptor to $G_{i}$ protein in human reproductive tract tumors. Journal of Clinical Endocrinology and Metabolism 81 3249-3253.

Imai A, Takagi A, Horibe S, Takagi H \& Tamaya T 1998 Fas and Fas ligand system may mediate antiproliferative activity of gonadotropin-releasing hormone receptor in endometrial cancer cells. International Journal of Oncology 13 97-100.

Irmer G, Burger C, Ortmann O, Schulz KD \& Emons G 1994 Expression of luteinizing hormone releasing hormone and its mRNA in human endometrial cancer cell lines. Journal of Clinical Endocrinology and Metabolism 79 916-919.

Irmer G, Bürger C, Müller R, Ortmann O, Peter U, Kakar SS, Neill JD, Schulz KD \& Emons G 1995 Expression of the messenger RNAs for luteinizing hormone-releasing hormone (LHRH) and its receptor in human ovarian epithelial carcinoma. Cancer Research 55 817-822.

Jeske NA, Glucksman MJ \& Roberts JL 2004 Metalloendopeptidase EC3.4.24.15 is constitutively released from the exofacial leaflet of lipid rafts in GT1-7 cells. Journal of Neurochemistry 90 819-828.

Jia YX, Yang JH, Pan CS, Geng B, Zhang J, Xiao Y, Gerns H, Yang J, Chang JK, Wen JK et al. 2006 Intermedin 1-53 protects the heart against isoproterenol-induced ischaemic injury in rats. European Journal of Pharmacology 549 117-123.

Jungwirth A, Schally AV, Halmos G, Groot K, Szepeshazi K, Pinski J \& Armatis P 1998 Inhibition of the growth of Caki-I human renal adenocarcinoma in vivo by luteinizing hormone-releasing hormone antagonist Cetrorelix, somatostatin analog RC-160, and bombesin antagonist RC-3940-II. Cancer 82 909-917.

Kakar SS, Grizzle WE \& Neill JD 1994 The nucleotide sequences of human $\mathrm{GnRH}$ receptors in breast and ovarian tumors are identical with that found in pituitary. Molecular and Cellular Endocrinology 106 145-149.

Kang SK, Cheng KW, Ngan ES, Chow BK, Choi KC \& Leung PC 2000 Differential expression of human gonadotropin-releasing hormone receptor gene in pituitary and ovarian cells. Molecular and Cellular Endocrinology 162 157-166.

Keller G, Schally AV, Gaiser T, Nagy A, Baker B, Westphal G, Halmos G \& Engel JB 2005 Human malignant melanomas express receptors for luteinizing hormone releasing hormone allowing targeted therapy with cytotoxic luteinizing hormone releasing hormone analogue. Cancer Research 65 5857-5863.

Kim SI, Grum-Tokars V, Swanson TA, Cotter EJ, Cahill PA, Roberts IL, Cummins PM \& Glucksman MJ 2003 Novel roles of neuropeptide processing enzymes: EC3.4.24.15 in the neurome. Journal of Neuroscience Research 74 456-467.

Klijn JG, Blamey RW, Boccardo F, Tominaga T, Duchateau L \& Sylvester R 2001 Combined tamoxifen and luteinizing hormone-releasing hormone (LHRH) agonist versus LHRH agonist alone in premenopausal advanced breast cancer: a meta-analysis of four randomized trials. Journal of Clinical Oncology 19 343-353.

Koob GF 1996 Drug addiction: the yin and yang of hedonic homeostasis. Neuron 16 893-896.

Kottler ML, Starzec A, Carre MC, Lagarde JP, Martin A \& Counis R 1997 The genes for gonadotropin-releasing hormone and its receptor are expressed in human breast with fibrocystic disease and cancer. International Journal of Cancer 71 595-599.
Kramer MS, Cutler N, Feighner J, Shrivastava R, Carman J, Sramek JJ, Reines SA, Liu G, Snavely D, Wyatt-Knowles E et al. 1998 Distinct mechanism for antidepressant activity by blockade of central substance $P$ receptors. Science 281 1640-1645.

Kreeger JS \& Larson AA 1996 The substance P amino-terminal metabolite substance $\mathrm{P}(1-7)$, administered peripherally, prevents the development of acute morphine tolerance and attenuates the expression of withdrawal in mice. Journal of Pharmacology and Experimental Therapeutics 279 662-667.

Krsmanovic LZ, Martinez-Fuentes AJ, Arora KK, Mores N, Navarro CE, Chen HC, Stojilkovic SS \& Catt KJ 1999 Autocrine regulation of gonadotropin-releasing hormone secretion in cultured hypothalamic neurons. Endocrinology 140 1423-1431.

Labrie F, Dupont A, Belanger A, Cusan L, Lacourciere Y, Monfette G, Laberge JG, Emond JP, Fazekas AT, Raynaud JP et al. 1982 New hormonal therapy in prostatic carcinoma: combined treatment with an LHRH agonist and an antiandrogen. Clinical and Investigative Medicine 5 267-275.

Lasdun A, Reznik S, Molineaux CJ \& Orlowski M 1989 Inhibition of endopeptidase 24.15 slows the in vivo degradation of luteinizing hormone-releasing hormone. Journal of Pharmacology and Experimental Therapeutics 251 439-447.

Latouche J, Crumeyrolle-Arias M, Jordan D, Kopp N, Augendre-Ferrante B, Cedard L \& Haour F $1989 \mathrm{GnRH}$ receptors in human granulosa cells: anatomical localization and characterization by autoradiographic study. Endocrinology 125 1739-1741.

Lau HL, Zhu XM, Leung PC, Chan LW, Chen GF, Chan PS, Yu KL \& Chan FL 2001 Detection of mRNA expression of gonadotropin-releasing hormone and its receptor in normal and neoplastic rat prostates. International Journal of Oncology 19 1193-1201.

Lembeck F \& Holzer P 1979 Substance P as neurogenic mediator of antidromic vasodilation and neurogenic plasma extravasation. Naunyn-Schmiedeberg's Archives of Pharmacology 310 175-183.

Leung PCK, Cheng CK \& Zhu X-M 2003 Multi-factorial role of GnRH-I and GnRH-II in the human ovary. Molecular and Cellular Endocrinology 202 145-153.

Lew RA, Tetaz TJ, Glucksman MJ, Roberts JL \& Smith Al 1994 Evidence for a two-step mechanism of gonadotropin-releasing hormone metabolism by prolyl endopeptidase and metalloendopeptidase EC 3.4.24.15 in ovine hypothalamic extracts. Journal of Biological Chemistry 269 12626-12632.

Lijnen PJ \& Petrov VV 2003 Role of intracardiac renin-angiotensinaldosterone system in extracellular matrix remodeling. Methods and Findings in Experimental and Clinical Pharmacology 25 541-564.

Limonta P, Dondi D, Moretti RM, Maggi R \& Motta M 1992 Antiproliferative effects of luteinizing hormone-releasing hormone agonists on the human prostatic cancer cell line LNCaP. Journal of Clinical Endocrinology and Metabolism 75 207-212.

Limonta P, Dondi D, Moretti RM, Fermo D, Garattini E \& Motta M 1993 Expression of luteinizing hormone-releasing hormone mRNA in the human prostatic cancer cell line LNCaP. Journal of Clinical Endocrinology and Metabolism 76 797-800.

Limonta P, Moretti RM, Marelli MM, Dondi D, Parenti M \& Motta M 1999 The luteinizing hormone-releasing hormone receptor in human prostate cancer cells: messenger ribonucleic acid expression, molecular size, signal transduction pathway. Endocrinology 140 5250-5256.

Limonta P, Moretti RM, Marelli MM \& Motta M 2003 The biology of gonadotropin hormone-releasing hormone: role in the control of tumor growth and progression in humans. Frontiers in Neuroendocrinology $\mathbf{2 4}$ 279-295

Loop SM, Gorder CA, Lewis SM, Saiers JH, Drivdahl RH \& Ostenson RC 1995 Growth inhibition of human prostate tumor cells by an agonist of gonadotrophin-releasing hormone. Prostate 26 179-188.

Meunier JC 1997 Nociceptin/orphanin FQ and the opioid receptor-like ORL1 receptor. European Journal of Pharmacology 340 1-15.

Millar RP $2005 \mathrm{GnRH}$ and GnRH receptors. Animal Reproduction Science 88 5-28.

Mimeault M, Quirion R, Dumont Y, St-Pierre S \& Fournier A 1992 Structure-activity study of hCGRP8-37, a calcitonin gene-related peptide receptor antagonist. Journal of Medicinal Chemistry 35 2163-2168.

Minaretzis D, Alper MM, Oskowitz SP, Lobel SM, Mortola JF \& Pavlou SN 1995 Gonadotropin-releasing hormone antagonist versus agonist 
administration in women undergoing controlled ovarian hyperstimulation: cycle performance and in vitro steroidogenesis of granulosa-lutein cells. American Journal of Obstetrics and Gynecology 172 1518-1525.

Montiel JL, Cornille F, Roques BP \& Noble F 1997 Nociceptin/orphanin FQ metabolism: role of aminopeptidase and endopeptidase 24.15. Journal of Neurochemistry 68 354-361.

Moretti RM, Montagnani Marelli M, Van Groeninghen JC \& Limonta P 2002 Locally expressed LHRH receptors mediate the oncostatic and antimetastatic activity of LHRH agonists on melanoma cells. Journal of Clinical Endocrinology and Metabolism 87 3791-3797.

Müller FO, Terblanchè J, Schall R, van Zyl Smit R, Tucker T, Marais K, Groenewoud G, Porchet HC, Weiner H \& Hawarden D 1997 Pharmacokinetics of triptorelin after intravenous bolus administration in healthy males and in males with renal or hepatic insufficiency. British Journal of Clinical Pharmacology 44 335-341.

Murdoch WJ 1995 Immunolocalization of a gonadotropin-releasing hormone receptor site in murine endometrium that mediates apoptosis. Cell and Tissue Research 282 527-529.

Murphey LJ, Gainer JV, Vaughan DE \& Brown NJ 2000 Angiotensinconverting enzyme insertion/deletion polymorphism modulates the human in vivo metabolism of bradykinin. Circulation 102 829-832.

Murphey LJ, Malave HA, Petro J, Biaggioni I, Byrne DW, Vaughan DE, Luther JM, Pretorius M \& Brown NJ 2006 Bradykinin and its metabolite bradykinin 1-5 inhibit thrombin-induced platelet aggregation in humans. Journal of Pharmacology and Experimental Therapeutics 318 1287-1292.

Nakayama Y, Takano Y, Shimohigashi Y, Tanabe S, Fujita T, Kamiya H \& Tsujimoto G 2000 Pharmacological characterization of a novel AVP(4-9) binding site in rat hippocampus. Brain Research 858 416-423.

Nohr D, Schäfer MK, Persson S, Romeo H, Nyberg F, Post C, Ekström G \& Weihe E 1999 Calcitonin gene-related peptide gene expression in collagen-induced arthritis is differentially regulated in primary afferents and motoneurons: influence of glucocorticoids. Neuroscience 93 759-773.

Nyberg F \& Silberring J 1990 Conversion of the dynorphins to Leuenkephalin in human spinal cord. Progress in Clinical and Biological Research 328 261-265.

Nyberg F, Kankaanranta S, Brostedt P \& Silberring J 1991 Purification and characterization of endoproteases from human choroid plexus cleaving prodynorphin-derived opioid peptides. Brain Research 552 129-135.

Ohno T, Imai A, Furui T, Takahashi K \& Tamaya T 1993 Presence of gonadotropin-releasing hormone and its messenger ribonucleic acid in human ovarian epithelial carcinoma. American Journal of Obstetrics and Gynecology 169 605-610.

Orlowski M, Michaud C \& Chu TG 1983 A soluble metalloendopeptidase from rat brain. Purification of the enzyme and determination of specificity with synthetic and natural peptides. European Journal of Biochemistry 135 81-88.

Orlowski M, Reznik S, Ayala J \& Pierotti AR 1989 Endopeptidase 24.15 from rat testes. Isolation of the enzyme and its specificity toward synthetic and natural peptides, including enkephalin-containing peptides. Biochemical Journal 261 951-958.

Peng C, Fan NC, Ligier M, Vannanen J \& Leung PCK 1994 Expression and regulatin of gonadotropin-releasing hormone $(\mathrm{GnRH})$ and $\mathrm{GnRH}$ receptor messenger ribonucleic acids in human granulose-luteal cells. Endocrinology 135 1740-1746.

Pierotti AR, Lasdun A, Ayala JM, Roberts JL \& Molineaux CJ 1991 Endopeptidase-24.15 in rat hypothalamic/pituitary/gonadal axis. Molecular and Cellular Endocrinology 76 95-103.

Pineau C, McCool S, Glucksman MJ, Jegou B \& Pierotti AR 1999 Distribution of thimet oligopeptidase (E.C. 3.4.24.15) in human and rat testes. Journal of Cell Science 112 3455-3462.

Plosker GL \& Brogden RN 1994 Leuprorelin. A review of its pharmacology and therapeutic use in prostatic cancer, endometriosis and other sex hormone-related disorders. Drugs 48 930-967.

Powell JF, Reska-Skinner SM, Prakash MO, Fischer WH, Park M, Rivier JE, Craig AG, Mackie GO \& Sherwood NM 1996 Two new forms of gonadotropin-releasing hormone in a protochordate and the evolutionary implications. PNAS 93 10461-10464.
Raga F, Casañ EM, Kruessel JS, Wen Y, Huang HY, Nezhat C \& Polan ML 1998 Quantitative gonadotropin-releasing hormone gene expression and immunohistochemical localization in human endometrium throughout the menstrual cycle. Biology of Reproduction 59 661-669.

Ramakrishnappa N, Rajamahendran R, Lin Y-M \& Leung PCK 2005 GnRH in non-hypothalamic reproductive tissues. Animal Reproduction Science 88 95-113.

Rastogi RK, Di Fiore MM, D'Aniello A, lela L \& Fiorentino M 2002 GnRH in the invertebrates: an overview. Progress in Brain Research 141 19-29.

Ray K, Hines CS, Coll-Rodriguez J \& Rodgers DW 2004 Crystal structure of human thimet oligopeptidase provides insight into substrate recognition, regulation, and localization. Journal of Biological Chemistry 279 20480-20489.

Rossi GC, Leventhal L, Bolan E \& Pasternak GW 1997 Pharmacological characterization of orphanin $\mathrm{FQ}$ /nociceptin and its fragments. Journal of Pharmacology and Experimental Therapeutics 282 858-865.

Sampaio WO, Nascimento AA \& Santos RA 2003 Systemic and regional hemodynamic effects of angiotensin-(1-7) in rats. American Journal of Physiology. Heart and Circulatory Physiology 284 H1985-H1994.

Santos RA, Ferreira AJ \& Simões E Silva AC 2008 Recent advances in the angiotensin-converting enzyme 2-angiotensin(1-7)-Mas axis. Experimental Physiology 93 519-527.

Schally AV 1999 Luteinizing hormone-releasing hormone analogs: their impact on the control of tumorigenesis. Peptides 20 1247-1262.

Schally AV, Comaru-Schally AM, Nagy A, Kovacs M, Szepeshazi K, Plonowski A, Varga JL \& Halmos G 2001 Hypothalamic hormones and cancer. Frontiers in Neuroendocrinology 22 248-291.

Schneider F, Tomek W \& Grundker C 2006 Gonadotropin-releasing hormone $(\mathrm{GnRH})$ and its natural analogues: a review. Theriogenology 66 691-709.

Shaikh MB, Steinberg A \& Siegel A 1993 Evidence that substance P is utilized in medial amygdaloid facilitation of defensive rage behavior in the cat. Brain Research 625 283-294.

Sharpe LG \& Jaffe JH 1989 Captopril and capsaicin modify opioid withdrawal in the morphine-dependent rat. Pharmacology, Biochemistry, and Behavior 33 899-902.

Skidgel RA, Engelbrecht S, Johnson AR \& Erdös EG 1984 Hydrolysis of substance $P$ and neurotensin by converting enzyme and neutral endopeptidase. Peptides 5 769-776.

Sogani PC \& Fair WR 1987 Treatment of advanced prostatic cancer. Urologic Clinics of North America 14 353-371.

Stewart JM, Hall ME, Harkins J, Frederickson RC, Terenius L, Hökfelt T \& Krivoy WA 1982 A fragment of substance P with specific central activity: SP(1-7). Peptides 3 851-857.

Swanson TA, Kim SI, Myers M, Pabon A, Philibert KD, Wang M \& Glucksman MJ 2004 The role of neuropeptide processing enzymes in endocrine (prostate) cancer: EC 3.4.24.15 (EP 24.15). Protein and Peptide Letters 11 471-478.

Tieva A, Stattin P, Wikström P, Bergh A \& Damber JE 2001 Gonadotropinreleasing hormone receptor expression in the human prostate. Prostate 47 276-284.

Tiong JD, Pakiam JG \& Wray S 2004 Gonadotropin releasing hormone-1 expression in incisors of mice. Endocrinology 145 3608-3612.

Tsai PS 2006 Gonadotropin-releasing hormone in invertebrates: structure, function and evolution. General and Comparative Endocrinology 148 48-53.

Tullai JW, Cummins PM, Pabon A, Roberts JL, Lopingco MC, Shrimpton CN, Smith AI, Martignetti JA, Ferro ES \& Glucksman MJ 2000 The neuropeptide processing enzyme EC 3.4.24.15 is modulated by protein kinase A phosphorylation. Journal of Biological Chemistry 275 36514-36522.

Vincze B, Pályi I, Daubner D, Kremmer T, Számel I, Bodrogi I, Sugár J, Seprödi J, Mezö I, Teplán I et al. 1991 Influence of luteinizing hormonereleasing hormone agonists on human mammary carcinoma cell lines and their xenografts. Journal of Steroid Biochemistry and Molecular Biology 38 119-126.

Walters K, Chin YP \& Wu TJ 2007 A processed metabolite of luteinizing hormone-releasing hormone has proliferative effects in endometrial cells. American Journal of Obstetrics and Gynecology 196 $33 \mathrm{e} 1-33 \mathrm{e} 5$ 
Walters K, Wegorzewska IN, Chin YP, Parikh MG \& Wu TJ 2008 Luteinizing hormone-releasing hormone I (LHRH-I) and its metabolite in peripheral tissues. Experimental Biology and Medicine 233 123-130.

Wang XC \& Burbach JP 1986 Formation of metabolites of [Arg8]vasopressin (AVP) by brain peptidases. Conversion of the intermediate [Cyt6]AVP(3-9). FEBS Letters 197 164-168.

Warner FJ, Smith AI, Hooper NM \& Turner AJ 2004 Angiotensin-converting enzyme-2: a molecular and cellular perspective. Cellular and Molecular Life Sciences $612704-2713$.

de Wied D, Diamant M \& Fodor M 1993 Central nervous system effects of the neurohypophyseal hormones and related peptides. Frontiers in Neuroendocrinology 14 251-302.

Wiktelius D, Khalil Z \& Nyberg F 2006 Modulation of peripheral inflammation by the substance $\mathrm{P} N$-terminal metabolite substance P1-7. Peptides 27 1490-1497.

Wolfahrt S, Kleine B \& Rossmanith WG 1998 Detection of gonadotrophin releasing hormone and its receptor mRNA in human placental trophoblasts using in situ reverse transcription-polymerase chain reaction. Molecular Human Reproduction 4 999-1006.

Wray S 2002 Development of gonadotropin-releasing hormone-I neurons. Frontiers in Neuroendocrinology 23 292-316.

Wu TJ, Pierotti AR, Jakubowski M, Sheward WJ, Glucksman MJ, Smith AI, King JC, Fink G \& Roberts JL 1997 Endopeptidase EC 3.4.24.15 presence in the rat median eminence and hypophysial portal blood and its modulation of the luteinizing hormone surge. Journal of Neuroendocrinology 9 813-822.

Wu TJ, Mani SK, Glucksman MJ \& Roberts JL 2005 Stimulation of luteinizing hormone-releasing hormone (LHRH) gene expression in GT1-7 cells by its metabolite, LHRH-(1-5). Endocrinology 146 280-286.

Wu TJ, Glucksman MJ, Roberts JL \& Mani SK 2006 Facilitation of lordosis in rats by a metabolite of luteinizing hormone releasing hormone. Endocrinology 147 2544-2549.

Wu HM, Wang HS, Huang HY, Soong YK, MacCalman CD \& Leung PC 2009 GnRH signaling in intrauterine tissues. Reproduction 137 769-777.

Yano T, Yano N, Matsumi H, Morita Y, Tsutsumi O, Schally AV \& Taketani Y 1997 Effect of luteinizing hormone-releasing hormone analogs on the rat ovarian follicle development. Hormone Research 48 35-41.

Zubrzycka M \& Janecka A 2000 Substance P: transmitter of nociception. Endocrine Regulations 34 195-201.

Received 31 March 2009

First decision 1 May 2009

Revised manuscript received 25 August 2009

Accepted 15 September 2009 